\title{
KAJIAN PEMANFAATAN ENZIM DALAM PENGOLAHAN WINE BERBASIS PISANG LOKAL
}

\author{
Bryan Raharja, Yosua Wira Adi Nugroho, dan Warsono El Kiyat \\ Departemen Teknologi Pangan dan Gizi, Fakultas Ilmu Hayati, Universitas Surya, \\ JI. MH. Thamrin Km 2.7, Banten 15117, Indonesia, email: warsono.el.kiyat@gmail.com
}

\begin{abstract}
Abstrak
Pisang merupakan salah satu komoditas unggulan Indonesia. Salah satu produk turunan dari pisang yang tinggi nilainya ialah wine. Namun, pisang mengandung berbagai polisakarida,seperti: pektin, pati, dan xilan yang dapat menyebabkan warnanya keruh dan kental bila dibuat wine. Berdasarkan hasil studi, proses enzimatis sari pisang dengan kelompok enzim lignoselulolitik (pektinase, selulase, dan hemiselulase) dapat mendegradasi polisakarida seperti pektin, pati, dan xilan pada sari buah pisang sehingga menghasilkan produk yang jernih dan yield yang lebih banyak. Penggunaan enzim $\alpha$-amilase dapat meningkatkan kadar gula terlarut dan pereduksi sari pisang yang berpengaruh terhadap pembentukan etanol. Sonikasi secara tunggal tidak berpengaruh signifikan terhadap yield dan kejernihan sampel namun berpengaruh signifikan bila digabungkan dengan enzim pektinase dan selulase. Penggunaan jenis enzim yang berbeda dapat mempengaruhi dan memberikan presepsi sensori yang berbeda.
\end{abstract}

Kata kunci: enzim lignoselulolitik, klarifikasi, sonikasi, wine

\section{Abstract}

Banana is one of Indonesia's leading commodities. One of the most valuable banana derivatives product is wine. Banana contain various polysaccharides pectin, starch, and xylan which can cause the cloudiness and thick consistency when processed into wine. Several studies showed enzymatic processing witha lignocellulolyticenzyme group (pectinase, cellulase, and hemicellulase) can degrade polysaccharides such as pectin, starch, and xylan in banana extracts to produce crystal clear and higher yields. The use of $\alpha$-amylase enzyme can increase dissolved sugar and reducing sugar in the banana extract that affects ethanol formation. Sonication alone did not have a significant impact on the yield and clarity of the sample but had a significant impact when combined with pectinase and cellulase enzymes. The use of different types of enzymes may affect and provide different sensory perception.

Keywords: clarification, lignocellulolytic enzyme, sonication, wine

\section{PENDAHULUAN}

Pisang merupakan buah yang berasal dari kawasan Asia Tenggara. Tanaman buah ini kemudian menyebar ke Afrika, Amerika Selatan dan Tengah. Saat ini, budidaya pisang dilakukan secara intensif untuk memenuhi kebutuhan domestik maupun kebutuhan ekspor. Indonesia merupakan produsen pisang nomor 7 terbesar di dunia dengan kontribusi produksi sebesar 5,97\% (Susanti, 2014). Hal ini didukung dengan peningkatan rata-rata produksi pisang sebesar 4,16\% per tahun (Rohmah, 2016). Ketersediaan pisang yang melimpah mendorong masyarakat dan industri untuk mengolah pisang menjadi berbagai produk olahan guna memperpanjang umur simpan dan meningkatkan nilai dari buah pisang. Kebanyakan produk pangan turunan pisang diolah dari daging buahnya, sedangkan kulitnya tidak dimanfaatkan dan dibuang. Menurut Bazirake (2008), kulit pisang juga dapat diolah bersama dengan daging buahnya menjadi produk olahan seperti jus pisang atau wine.

Salah satu produk turunan pisang yang tinggi nilainya ialah wine. Wine merupakan minuman beralkohol yang terbuat dari hasil fermentasi buah. Namun, pisang mengandung berbagai polisakarida pektin, pati, dan xilan yang dapat menyebabkan warnanya keruh dan kental bila diolah menjadi jus maupun 
Agrisaintifika

Jurnal Ilmu-Ilmu Pertanian

Vol. 2, No. 2, 2018

Raharja, et al., 2018

wine (Gupta, 2016). Pektin menyebabkan proses klarifikasi menjadi lebih sulit karena struktur molekulnya yang sangat mirip dengan serat. Pati membuat filtrasi menjadi lebih sulit dan membuat jus menjadi keruh (Elena et al., 2004). Untuk mengatasi hal tersebut dibutuhkan pengolahan yang tepat untuk menjernihkan jus yang akan dibuat menjadi wine. Proses klarifikasi/penjernihan tersebut bertujuan untuk menghilangkan padatan tidak terlarut dan menghancurkan senyawa pektin dan pati dengan bantuan enzim spesifik (Chersilp dan Umsakul, 2008). Menurut Dufour dan Bayanove (1999), kualitas wine dipengaruhi kejernihan, rasa dan aroma wine. Di sisi lain viskositas dari wine dapat mempengaruhi mouthfeelnya. Viskositas dan turbiditas (kekeruhan) yang menurun dapat meningkatkan kejernihan dari wine (Bates et al., 2001).

Proses klarifikasi yang tepat dengan pemanfaatan enzim spesifik akan menghasilkan wine yang jernih dengan kualitas yang baik. Berdasarkan uraian tersebut, enzim memiliki peranan penting dalam pengolahan jus pisang untuk menghasilkan wine dengan kualitas yang baik. Oleh karena itu, perlu dilakukan kajian terhadap potensi enzim dalam pengembangan wine dengan memanfaatkan pisang secara utuh khususnya pisang lokal Indonesia seperti pisang ambon, pisang raja, pisang barangan dan kultivar lainnya.

\section{PROSES ENZIMATIS PRODUKSI WINE PISANG}

Menurut Cheirsilp dan Usmakul (2008) penambahan enzim dilakukan pada jus buah pisang sebelum proses fermentasi menjadi wine. Beberapa literatur menunjukkan bahwa enzim yang dapat digunakan antara lain amilase, pektinase, selulase, dan hemiselulase sebagaimana disajikan pada Gambar 1.

\section{PEMANFAATAN ENZIM PEKTINASE DAN AMILASE DALAM PENGOLAHAN WINE PISANG}

Pemrosesan buah pisang dengan enzim dilakukan sebelum proses fermentasi wine. Secara garis besar pembuatan wine pisang dengan enzim dibagi menjadi dua tahap yakni penjernihan jus pisang dengan enzim-enzim golongan lignoselulolitik seperti pektinase dan selulase serta penguraian pati menjadi gula sederhana oleh amilase dan glukanase. Pektinase merupakan kelompok besar enzim yang memecah polisakarida pada jaringan tumbuhan menjadi molekul sederhana seperti asam galakturonat. Penambahan enzim pektinase pada jus pisang dapat menurunkan viskositas dan meningkatkan volume rendemen seiring dengan konsentrasi penambahan. Penambahan enzim $\alpha$-amilase juga meningkatkan baik kadar gula terlarut maupun gula pereduksi dalam jus pisang. Waktu proses dengan enzim meningkatkan rendemen sampai titik tertentu sebelum tercapai titik jenuh di mana tidak ada lagi substrat tersedia. Seperti pada hasil penelitian Cheirsilp dan Usmakul (2008) yang ditunjukkan pada Tabel 1 dan Tabel 2.

Pisang yang diberi perlakuan non-enzimatis digunakan sebagai kontrol. Volume jus yang diekstraksi setelah perlakuan dengan 0,0125\% (b/b) pektinase 2,7 kali lipat lebih tinggi $(56 \mathrm{~mL})$ dibandingkan dengan kontrol $(16 \mathrm{~mL})$. Hal ini dapat dijelaskan oleh pektinase yang menghancurkan molekul pektin, yang menyebabkan pengurangan kapasitas menahan air, dan akibatnya, lebih banyak air bebas dilepaskan dari sistem. Pada konsentrasi pektinase lebih tinggi dari $0,0125 \%$ dan sampai $0,1 \%(\mathrm{~b} / \mathrm{b})$, tidak ada perbedaan yang signifikan dalam volume jus yang diekstrak seperti ditunjukkan pada Tabel 1 ( $P>0,05)$. Di sisi lain, seiring konsentrasi pektinase meningkat, viskositas menurun (Tabel 1). Ini berarti bahwa viskositas adalah parameter yang lebih baik untuk mengevaluasi efek hidrolisis pektinase dibandingkan dengan volume jus yang diekstraksi. Namun, penggandaan konsentrasi pektinase dari 0,05 sampai $0,1 \%(\mathrm{~b} / \mathrm{b})$ hanya menyebabkan reduksi $13 \%$ viskositas (dari 251 
Agrisaintifika

Jurnal Ilmu-Ilmu Pertanian

Vol. 2, No. 2, 2018

Raharja, et al., 2018

menjadi $218 \mathrm{cP}$ ) (Tabel 1). Hal ini disebabkan oleh penambahan enzim yang lebih banyak yang tentunya dapat meningkatkan biaya operasi, studi lebih lanjut menggunakan konsentrasi pektinase $0,05 \%$ (b/b), yang menghasilkan peningkatan volume jus ekstraksi 2,7 kali lipat dan penurunan viskositas $46 \%$. Perlakuan dengan lama waktu lebih dari 1 jam tidak menghasilkan perbedaan signifikan $(P>0,05)$ terhadap volume jus yang diekstraksi (Tabel 2), namun reduksi viskositasnya signifikan (26, 46, 51 dan $55 \%$ pada waktu perlakuan 0,$5 ; 1 ; 1,5$ dan 2 jam, masing-masing). Jika diasumsikan bahwa reduksi viskositas adalah ukuran tingkat hidrolisis yang disebabkan oleh pektinase, maka hidrolisis maksimum dicapai dalam 2 jam. Oleh karena itu, konsentrasi pektinase $0,05 \%$ (b/b) dan 2 jam waktu perlakuan digunakan untuk menghidrolisis pisang.

Hasil penelitian Cheirsilp dan Usmakul (2008) juga menunjukkan bahwa seiring dengan penambahan konsentrasi pektinase terus terjadi penambahan rendemen dan pengurangan viskositas. Namun dari pengujian statistik tidak ada perbedaan nyata hasil rendemen antara kadar pektinase $0,0125 \%, 0,05 \%$, dan $0,1 \%$. Meski demikian, terdapat perbedaan variable viskositas yang nyata untuk setiap konsentrasi pektinase. Viskositas jus berkaitan erat dengan kejernihan wine sehingga pengurangan viskositas memegang peranan penting (Panesar et al., 2010).

Meski berbeda signifikan secara statistik, namun pada konsentrasi penambahan 0,05\% dan $0,1 \%$ perbedaan viskositas hanya $18 \%$. Perlu menjadi catatan bahwa dengan menaikkan konsentrasi enzim dapat terjadi peningkatan biaya produksi sehingga perlu dipertimbangkan antara jumlah yang ditambahkan dengan efek yang dihasilkan. Pada konsentrasi $0,05 \%$ tidak ada perbedaan yang signifikan untuk rendemen pada waktu proses setelah 1 jam tetapi terdapat perbedaan nyata untuk viskositas. Sehingga untuk penambahan pektinasi yang optimum ialah 0,05\% dengan waktu 2 jam dengan kekentalan akhir. Sebagai pembanding studi lain yang dilakukan oleh Tapre dan Jain (2014) merekomendasikan penggunaan enzim pektinase dengan konsentrasi $0,12 \%$ pada $38,84^{\circ} \mathrm{C}$ selama 136,52 menit menghasilkan kekentalan produk sebesar 450,20 Cp yang lebih besar dari nilai penelitian Cheirslip \& Usmakul (2008) pada konsentrasi $0,05 \%$ pada $40^{\circ} \mathrm{C}$ selama 120 menit sebesar $207 \mathrm{Cp}$ yang menunjukkan degradasi pektin yang lebih optimum.

Penelitian lain yang dilakukan oleh Sagu et al. (2014) melakukan studi kinetik dan kondisi optimum depektinasi dengan menggunakan pektinase pada pemrosesan buah pisang menjadi sari buah pisang. Data yang dihasilkan menunjukkan penurunan viskositas dan padatan tak terlarut dengan alkohol seiring dengan penambahan waktu dan konsentrasi pektinase. Penambahan temperatur proses menyebabkan penurunan kadar polifenol dan protein pada rendemen. Pada penelitian tersebut,digunakan temperatur sebesar $30-60^{\circ} \mathrm{C}$; dengan waktu reaksi selama 20 -120 menit dan konsentrasi pektinase sebesar 0,01 hingga $0,05 \% \mathrm{v} / \mathrm{w}$. Hubungan antara faktor-faktor yakni konsentrasi, waktu dan temperatur dapat digambarkan dengan persamaan polinomial seperti yang ditunjukkan pada Tabel 3.

Menurut Sagu et al. (2014) disebutkan bahwa waktu untuk mencapai depektinasi maksimum ialah dalam waktu dua jam. Namun dalam praktiknya perlu dipertimbangkan faktor biaya dan energi yang dibutuhkan. Konsentrasi pektinase yang semakin tinggi juga memaksimalkan proses depektinasi namun konsentrasi yang semakin tinggi juga akan meningkatkan biaya proses. Berdasarkan perhitungan optimisasi didapatkan kondisi yang paling optimum pada temperatur $33^{\circ} \mathrm{C}$ selama 108 menit dengan konsentrasi pektinase 0,03\% (\%v/w) (Sagu et al., 2014).

Kulit pisang yang merupakan limbah dari kebanyakan proses pembuatan sari pisang dapat dimanfaatkan kembali sebagai substrat pembentukan pektinase oleh Aspergillus niger. Penelitian yang dilakukan oleh Barman et al. (2014) menunjukkan bahwa aktivitas poligalakturonase pada pektinase meningkat 
Agrisaintifika

Jurnal Ilmu-Ilmu Pertanian

Vol. 2, No. 2, 2018

Raharja, et al., 2018

seiring dengan waktu inkubasi Aspergillus niger namun ketika mencapai titik tertentu terjadi penurunan aktivitas poligalakturonase yang disebabkan oleh deaktivasi enzim - enzim ketika mencapai waktu tertentu yang disebabkan denaturasi struktur 3Ddari proteinnya. Hal ini juga dapat disebabkan oleh seiring waktu terjadi penurunan jumlah substrat dalam lingkungan inkubasi. Hal ini terlihat pada substrat dengan konsentrasi tinggi yang memiliki aktivitas poligalakturonase yang lebih tinggi pada awalnya tetapi tidak ada perbedaan signifikan pada waktu yang lebih lama. Sebagaimana faktor lainnya, temperatur juga mempengaruhi dimana peningkatan suhu sampai titik optimumnya dapat meningkatkan aktivitas poligalakturonase enzim yang diproduksi sebagaimana ditunjukkan pada Tabel 4.

Seperti yang disajikan pada Tabel 4. dengan analisis "desirability function", diketahui kondisi optimum untuk produksi enzim pektinasi dari kulit pisang ialah pada konsentrasi substrat $8,07 \%$, waktu inkubasi selama 65,82 jam, pada suhu $32,37^{\circ} \mathrm{C}$. Pada aplikasinya dalam klarifikasi jus pisang, enzim yang telah dipurifikasi parsial memiliki tingkat kejernihan yang lebih tinggi ditunjukan dari nilai absorbansinya. Di sisi lain, konsentasi dan perlakuan pada enzim tidak menunjukkan perubahan signifikan terhadap tingkat keasaman sari pisang sebagaimana ditunjukkan pada Tabel 5.

Pada penelitian yang juga dilakukan oleh Chersilp dan Usmakul (2008), dilakukan juga terhadap konsentrasi dan waktu proses dengan enzim amilase dengan hasil seperti yang ditunjukkan pada Tabel 6 dan Tabel 7.Setelah perlakuan dengan pektinase, $\alpha$-amilase digunakan untuk menghidrolisis pati dan memperpendek rantai glukosidik pati. Total gula larut dan gula pereduksi diukur untuk mengevaluasi hidrolisis pati. Efek dari konsentrasi a-amilase yang berbeda dan waktu perlakuan pada total gula terlarut dan gula pereduksi. Pisang yang diberi perlakuan nonenzim dijadikan sebagai kontrol. Pisang dengan perlakuan pektinase saja digunakan sebagai kontrol yang diberi perlakuan dengan pektinase. Pisang memiliki total gula terlarut 13 dan $27 \%$ (dari 104,25 sampai $117,61 \mathrm{mg} / \mathrm{mL}$ ) dan mengurangi gula (dari 64,19 sampai $81,53 \mathrm{mg} / \mathrm{mL}$ ), setelah perlakuan dengan pektinase. Perlakuan selanjutnya dengan konsentrasi $\alpha$-amilase $0,05 \%$ (b/b) selama 3 jam menghasilkan peningkatan $1,6 \%$ total gula terlarut (dari 117,61 sampai $119,50 \mathrm{mg} / \mathrm{mL}$ ) dan peningkatan gula pengurang sebesar 9,4\% (dari 81,53 sampai 89,19 mg $/ \mathrm{mL}$ ) selama kontrol yang diberi perlakuan dengan pektinase. Peningkatan konsentrasi amilase lebih lanjut dari 0,05 sampai 0,5\% (b/b) menghasilkan peningkatan lebih lanjut pada total gula terlarut (dari 119,50 sampai $127,99 \mathrm{mg} / \mathrm{mL}$ ) namun tidak berpengaruh signifikan terhadap gula pereduksi (Tabel 6). Meningkatnya waktu inkubasi dari 3 jam sampai 12 jam juga tidak berpengaruh signifikan terhadap kadar gula (Tabel 7). Namun, pada suhu gelatinisasi $\left(80^{\circ} \mathrm{C}\right)$, enzim bisa mudah diinaktivasi. Oleh karena itu, konsentrasi aamilase $0,05 \%(\mathrm{~b} / \mathrm{b})$ dengan waktu inkubasi 3 jam digunakan untuk pisang harus dilakukan setelah diberikan pektinase. Perlakuan pektinase dan aamilase selanjutnya menghasilkan total gula terlarut $15 \%$ dan $39 \%$ (dari 104,25 sampai 119,50 $\mathrm{mg} / \mathrm{mL}$ ) dan mengurangi gula (masing-masing 64,19 sampai $89,19 \mathrm{mg} / \mathrm{mL}$ ).

Dari data di atas diketahui dengan hanya penambahan enzim pektinase terjadi kenaikan baik gula pereduksi maupun gula terlarut masingmasing sebesar $13 \%$ dan $27 \%$. Penambahan enzim $\alpha$-amilase menaikkan jumlah gula terlarut dan gula pereduksi namun tidak signifikan yakni pada konsentrasi penambahan sebesar $0,5 \%$, kenaikan kadar gula hanya sebesar $8,83 \%$ pada gula terlarut dan $11,60 \%$ untuk gula pereduksi pasca penambahan pektinase. Hasil penelitian lain yang dilakukan oleh Zaker et al. (2014) menunjukkan penambahan enzim a-amilase dengan konsentrasi $0,5 \%$ meningkatkan kadar gula sebanyak $14,5 \%$ untuk gula terlarut dan $30,53 \%$ untuk gula pereduksi. Pada pembuatan wine kadar gula pereduksi utamanya glukosa dan fruktosa memegang peran penting terhadap kadar alkohol dari wine yang dihasilkan. Bila dibandingkan dengan anggur, anggur dapat mengandung glukosa hingga 45,86-122,89 $\mathrm{mg} / \mathrm{mL}$ dan fruktosa hingga $47,64-131,04 \mathrm{mg} / \mathrm{mL}$ 
Agrisaintifika

Jurnal Ilmu-Ilmu Pertanian

Vol. 2, No. 2, 2018

Raharja, et al., 2018

sehingga anggur dapat mengandung lebih banyak gula pereduksi dari sampel buah pisang yang telah diproses secara enzimatis (Jordãoet al., 2015). Secara teoritis berdasarkan standar SNI kadar alkohol wine dapat berkisar antara 5 $15 \%$ namun di Eropa wine digolongkan beralkohol tinggi bila berkisar antara 14\%-16\% $\mathrm{v} / \mathrm{v}$ sedangkan wine beralkohol rendah berkisar antara 9\%-13\% v/v. Dewasa ini di Eropa berkembang tren untuk mengonsumsi wine dengan kadar alkohol lebih rendah bahkan beberapa negara menerapkan cukai tambahan untuk produk wine dengan kadar alkohol diatas 14,5\% (Massot et al., 2008). Pada wine pisang penelitian Cheirsilp dan Usmakul (2008) kadar alkohol mencapai 13,9 dan $14,4 \%$ v/v sehingga bila hendak mengikuti tren tersebut tidak diperlukan peningkatan kadar gula yang sangat ekstensif.

Kedua penelitian tersebut dilakukan pada suhu $50^{\circ} \mathrm{C}$ yang diketahui sebagai suhu optimum dari $\alpha$-amilase. Pada penelitian yang dilakukan oleh Cheirsilp dan Usmakul (2008) sampel wine yang diproses secara enzimatis empat kali lebih jernih sedangkan pada penelitian yang dilakukan Zaker et al. (2014) sampel wine yang diproses secara enzimatis tiga kali lebih jernih dari wine yang tidak diproses secara enzimatis setelah difermentasi selama 30 hari. Meski demikian hal ini dapat dipengaruhi perbedaan kultivar pisang dan stage kematangan pisang yang berbeda pada saat penelitian pada kedua penelitian.

Pada pembuatan wine dari pisang, Masalah lain yang tidak diinginkan ialah pencokelatan jus pisang sebelum fermentasi yang dapat diatasi dengan penambahan potassium metabisulphite atau potassium sorbat sebanyak 100 ppm dapat ditambahkan untuk mencegah pencokelatan pada sari buah pisang dan mencegah pertumbuhan mikroorganisme yang tidak diinginkan. Pisang yang telah lewat matang cenderung menghasilkan rendemen yang lebih banyak dengan kadar gula sederhana yang lebih tinggi (Byarugaba-Bazirake, 2008).

Pisang yang telah diolah menjadi wine dengan bantuan enzim memiliki karakteristik yang tentunya berbeda dengan jus pisang lainnya seperti yang ditunjukkan pada Tabel 8. Fermentasi anaerob dilakukan pada suhu $30,2^{\circ} \mathrm{C}$. Pada suhu ini, aktivitas pektinase dan $\alpha$-amilase lebih rendah dari pada suhu optimum masingmasing enzim. Oleh karena itu, perlakuan enzimatik dilakukan sebelum fermentasi wine. Konsentrasi padatan terlarut total, total gula larut dan alkohol dalam anggur pisang setelah 25 hari fermentasi ditunjukkan pada Tabel 8. Tidak ada perbedaan yang signifikan dalam konsentrasi akhir dari padatan terlarut total dan gula larut total dari anggur pisang yang diolah dengan enzim dibandingkan dengan kontrol. Karena gula larut total dari wine pisang yang diolah enzim disesuaikan ke tingkat yang sama seperti pada kontrol sebelum fermenasi, tidak ada perbedaan konsentrasi alkohol yang signifikan (Tabel 8).

\section{PENGARUH SONIKASI TERHADAP AKTIVITAS ENZIM LIGNO- SELULOLITIK}

Kelompok enzim ligninselulolitik yang dapat digunakan pada pembuatan wine pisang tidak hanya pektinase namun juga beberapa enzim lain. Penelitian yang dilakukan oleh Ibarra-Junquera et al. (2014) menggunakan Macerax PM yang merupakan kombinasi pektinase, selulase dan hemiselulase untuk mengekstrak jus pisang dengan jumlah optimum $150 \mu \mathrm{L}$ enzim/kg buah pisang. Selain itu penggunaan enzim juga dapat dikombinasikan dengan pemrosesan lain seperti sonikasi yang bertujuan memperbanyak rendemen seperti pada penelitian yang dilakukan Bora et al. (2017) seperti yang ditunjukkan pada Tabel 9 dan Tabel 10.Dari hasil pengujian tersebut diketahui bahwa efek penggunaan selulase secara tunggal berada dibawah pektinase baik dengan maupun tanpa sonikasi. Kondisi terbaik didapatkan dengan pencampuran enzim selulase dan pektinase disertai dengan sonikasi dengan perubahan yield dari $47,30 \%$ dengan tanpa perlakuan apapun hingga $89,4 \%$. Sonikasi secara tunggal tidak memberikan efek signifikan tetapi bekerja sinergis dengan aplikasi enzim. 
Agrisaintifika

Jurnal Ilmu-Ilmu Pertanian

Vol. 2, No. 2, 2018

Raharja, et al., 2018

\section{KARAKTERISTIK SENSORI WINE PISANG}

Penggunaan enzim yang berbeda juga dapat memberikan pengaruh presepsi sensoris yang berbeda terhadap wine. Dari uji terhadap berbagai enzim komersial baik terhadap yield maupun presepsi sensoris untuk pisang kayinja, diketahui enzim komersial Rapidase X-press (endopolygalacturonase, pectin lyase dan Pectinmethyl-esterase) menghasilkan yield $57.87 \%$ v/w, Rapidase CB (Pektinase, maltodekstrin, $\mathrm{NaCl}$ ) menghasilkan yield $52.27 \%$, OE-Lallzyme (pectinase) menghasilkan yield sebesar $49,60 \%$, rapidase TF (Pectinase, hemicellulase, cellulase) menghasilkan yield sebesar $51,17 \%$ yaitu untuk setiap enzim diaplikasikan sebanyak $0,03 \mathrm{~g} / \mathrm{kg}$ pisang. Yield jus pisang tanpa proses enzimatis sebesar 10,03\%. (Byarugaba-Bazirakeet et al., 2012) Dari uji sensori didapatkan presepsi rasa sebagai berikut (Gambar 2). Untuk parameter mouthfeel, aroma, rasa dan penerimaan terbaik didapatkan oleh sampel tanpa pemrosesan enzimatis dan paling tidak disukai pada sampel yang diproses menggunakan enzim rapidase express meskipun menghasilkan yield yang paling banyak. Flavor terbaik didapatkan pada sampel yang diproses menggunakan enzim rapidase TF dan yang paling tidak disukai pada sampel yang diproses dengan enzim rapidase express. Warna sari pisang terbaik didapatkan pada sampel yang diproses dengan enzim OE-lallzyme dan yang paling tidak disukai pada sampel rapidase TF dan Rapidase express. Tingkat keasaman tertinggi ada pada rapidase $\mathrm{CB}$ dan terendah pada sampel kontrol. Sari pisang tersebut kemudian diolah menjadi wine yang menghasilkan presepsi seperti yang ditunjukkan pada Tabel 11.

\section{KESIMPULAN}

Proses enzimatis sari pisang dengan kelompok enzim ligninselulolitik seperti pektinase, selulase, hemiselulase dan lainnya dapat mendegradasi polisakarida seperti pektin, pati, dan xilan dalam sari buah pisang menghasilkan produk yang jernih dan yield yang lebih banyak. Pada konsentrasi 0,05\% pektinase dapat menghasilkan wine pisang yang 2-3 kali lebih jernih. Proses dengan enzim pektinase optimum pada konsentrasi $0,05 \%$ pada $40^{\circ} \mathrm{C}$ selama 120 menit. Penggunaan enzim a-amilase dapat meningkatkan kadar gula terlarut dan pereduksi pada sari pisang yang berpengaruh terhadap pembentukan etanol. Penggunaan sonikasi secara tunggal tidak berdampak signifikan terhadap yield dan kejernihan sampel namun berdampak signifikan bila digabungkan dengan enzim pektinase dan selulase. Penggunaan jenis enzim yang berbeda dapat mempengaruhi dan memberikan presepsi sensori yang berbeda. Enzim lignoselulolitik dan $\alpha$-amilase berpotensi besar menghasilkan wine berbasis pisang lokal dengan mutu yang baik.

\section{DAFTAR PUSTAKA}

Bates, R.P., Morris, J. R., and Crandall, P. G. 2001. Principles and Practices of Small-and Medium-Scale Fruit Juice Processing. FAO Agricultural Services and Bulletin, Swiss.

Barman, S., Sit, N., Badwaik, L., and Deka, S. 2014. Pectinase Production by Aspergillus niger Using Banana (Musa balbisiana) Peel as Substrate and its Effect on Clarification of Banana Juice. Journal of Food Science and Technology.52(6):3579-3589.

Bora, B., Jyoti, S., Handique, J., Sit, N. 2017. Effect of Ultrasound and Enzymatic Pre-treatment on Yield and Properties of Banana Juice. Journal of Ultrason Sonochemistry. 37: 445-451. DOI: 10.1016/j.ultsonch.2017.01.039.

Byaruagaba-Bazirake, G.W. 2008. The Effect of Enzymatic Processing On Banana Juice and Wine [Dissertation]. Faculty 
Agrisaintifika

Jurnal Ilmu-Ilmu Pertanian

Vol. 2, No. 2, 2018

Raharja, et al., 2018

of AgriSciences, Stellenbosch University, Stellenbosch.

Byaruagaba-Bazirake G.W., Van Ransburg, Kyamuhangire, W. 2012. Characteristics of Enzyme-treated Banana Juice From Three Cultivars of Tropical and Subtropical Africa. African Journal of Food Science and Technology.3(10): 277-290.

Cheirslip, B.and Umsakul, K. 2008. Processing of Banana-Based Wine Product Using Pectinase and $\alpha$ Amylase. Journal of Food Engineering. 31: 78 - 90.

Dufour, C.and Bayonove, C. L. 2004. Influence of Wine Structurally Different Polysaccharides on Volatility of Aroma Substances in a Model System. Journal of Agricultural and Food Chemistry. 47: 671 - 677.

Elena, C.M., Ceci, L.N., and Lozano, L.E. 2004. Characterization of Starch in Apple Juice and Its Degradation by Amylases. Food Chemistry. 87: 173 178.

Gupta, V.G. 2016. New and Future Developments in Microbial Biotechnology and Bioengineering: Microbial Cellulase System Properties and Applications. Elsevier, USA. 203 pp.

Hartanto, R.and Sianturi, C. 2008. Perubahan Kimia, Fisika dan Lama Simpan Buah Pisang Muli dalam Penyimpanan Atmosfir Pasif. Prosiding Seminar Nasional Sains dan Teknologi Universitas Lampung. 17-18 November 2008. Hal. IX-107-IX-115.

Ibarra-Junquera, Escalante-Minakata, V., Chávez-Rodríguez, M. A., ComparanDueñas, I. A., Osuna-Castro, J. A., Ornelas-Paz, J., Pérez-Martínez, J. D., and Aguilar, C. N. 2014. Optimization,
Modeling, and Online Monitoring of the Enzymatic Extraction of Banana Juice. Journal of Food and Bioprocess Technology. 7(1): 71-83, DOI : 10.1007/s11947-013-1136-2

Jordão, António M., Vilela, A., and Cosme, F. 2015. From Sugar of Grape to Alcohol of Wine: Sensorial Impact of Alcohol in Wine. Journal of Beverages. 1: 292310.

Massot, A., Mietton-Peuchot, M., Peuchot, C., and Milisic, V. 2008. Nanofiltration and Reverse Osmosis in Winemaking. Desalination. 231: 283-289.

Panesar, P.S., Satwinder S.M., Harish, K.C. 2010. Enzymes in Food Processing: Fundamentals and Potential Applications. I.K. International Publishing House, India. 135 pp.

Rohmah, Y. 2016. Outlook Komoditas Pertanian Sub Sektor Hortikultura. Pusat Data dan Sistem Informasi Kementerian Pertanian, Jakarta.

Sagu, S.T., Nso, J., Karmakar, S., and De, S. 2014. Optimization of Low Temperature Extraction of Banana Juice using Commercial Pectinase. Food Chemistry. S03088146(13)01655-5.

Soares, M.M.C.N., Silva, R., Carmona, E.C., and Gomes, E. 2001. Pectinolytic Enzymes Production by Bacillus Species and Their Potential Application on Juice Extraction. World Journal Microbiology Biotechnology. 17: 79-82.

Susanti, A. 2014. Outlook Komoditi Pisang. Pusat Data dan Sistem Informasi Kementerian Pertanian, Jakarta.

Tapre, A.R., and Jain, R.K. 2013. Pectinases: Enzyme for Fruit Processing Industry. International Food Research Journal. 21(2): 447-453. 
Agrisaintifika

Jurnal Ilmu-Ilmu Pertanian

Vol. 2, No. 2, 2018

Raharja, et al., 2018

Zaker, M., Aleem, A., Syed, K.A., Harkal, R.S. 2014. Pre-treatment of Pectinase and Amylase on Production of Banana Based wine. International Journal of Processing \& Post Harvest Technology. 5(2): 145-150. 
Agrisaintifika

Jurnal Ilmu-Ilmu Pertanian

Vol. 2, No. 2, 2018

Raharja, et al., 2018

\section{LAMPIRAN}

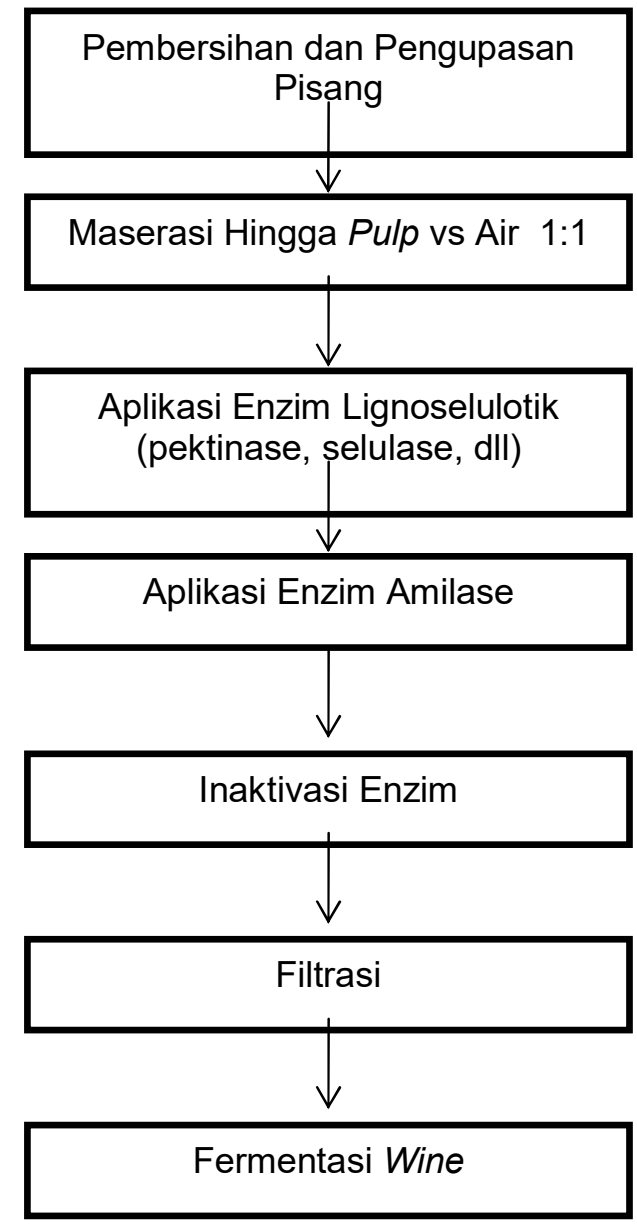

Gambar 1. Kombinasi Proses Enzimatis Pembuatan Wine Pisang(Chersilp dan Umsakul, 2008)

Tabel 1. Pengaruh Konsentrasi Enzim Pektinase dengan Rendemen dan Viskositas Jus Pisang

\begin{tabular}{cccc}
\hline $\begin{array}{c}\text { Konsentrasi } \\
\text { Pektinase (\% } \\
\text { w/w) }\end{array}$ & $\begin{array}{c}\text { Waktu } \\
\text { (jam) }\end{array}$ & $\begin{array}{c}\text { Volume } \\
\text { Ekstrak } \\
\text { Jus (mL) }\end{array}$ & $\begin{array}{c}\text { Viskositas } \\
\text { (cp) }\end{array}$ \\
\hline 0 & 0 & $16 \pm 0,5^{\mathrm{b}}$ & $465 \pm 2,08^{\mathrm{a}}$ \\
\hline 0,0125 & 1 & $56 \pm 1,00^{\mathrm{a}}$ & $335 \pm 7,02^{\mathrm{b}}$ \\
\hline 0,05 & 1 & $59 \pm 0,58^{\mathrm{a}}$ & $251 \pm 0,58^{\mathrm{c}}$ \\
\hline 0,10 & 1 & $61 \pm 0,58^{\mathrm{a}}$ & $218 \pm 8,74^{\mathrm{d}}$
\end{tabular}

Sumber: Chersilp dan Usmakul (2008) 
Tabel 2. Pengaruh Waktu Proses Pektinase dengan Rendemen dan Viskositas Jus Pisang

\begin{tabular}{cccc}
\hline $\begin{array}{c}\text { Konsentrasi Pektinase } \\
(\% \mathbf{w} / \mathbf{w})\end{array}$ & Waktu (jam) & $\begin{array}{c}\text { Volume Ekstrak } \\
\text { Jus (mL) }\end{array}$ & Viskositas (cp) \\
\hline 0,05 & 0,5 & $47 \pm 1,53^{\mathrm{b}}$ & $346 \pm 2,65^{\mathrm{a}}$ \\
\hline 0,05 & 1 & $59 \pm 0,58^{\mathrm{a}}$ & $251 \pm 0,58^{\mathrm{b}}$ \\
\hline 0,05 & 1,5 & $58 \pm 1,16^{\mathrm{a}}$ & $228 \pm 3,00^{\mathrm{c}}$ \\
\hline 0,05 & 2 & $59 \pm 1,53^{\mathrm{a}}$ & $207 \pm 4,36^{\mathrm{d}}$ \\
\hline
\end{tabular}

Chersilp dan Usmakul (2008)

Tabel 3. Hubungan Temperatur, Waktu, \& Konsentrasi terhadap Karakteristik Rendemen

\begin{tabular}{|c|c|c|}
\hline Karakteristik & Persamaan & $\mathbf{R}^{2}$ \\
\hline $\begin{array}{c}\text { Viskositas } \\
\text { (mPa.s) }\end{array}$ & $\begin{array}{c}=3.34-0.11 X_{1}+0.003 X_{2}+8.18 X_{3}+ \\
0.003 X_{1}^{2}-0.001 X_{1} X_{2}-1.41 X_{1} X_{3}+ \\
0.0001 X_{2}^{2}+0.35 X_{2} X_{3}+274.7 X_{3}^{2}\end{array}$ & 0,99 \\
\hline Kejernihan (\%T) & $\begin{array}{c}=-24.6+2.6 X_{1}+0,1 X_{2}-1312 X_{3}- \\
0.03 X_{1}^{2}-0.01 X_{1} X_{2}+9,6 X_{1} X_{3}+ \\
0.01 X_{2}^{2}+0.3 X_{2} X_{3}+2513 X_{3}^{2}\end{array}$ & 0,95 \\
\hline $\begin{array}{l}\text { Padatan Tak } \\
\text { Terlarut Alkohol } \\
\quad(\% \mathrm{w} / \mathrm{w})\end{array}$ & $\begin{array}{c}=0,22+0,002 X_{1}+0,012 X_{2}-0,82 X_{3}+ \\
0.0001 X_{1}^{2}-0.0001 X_{1} X_{2}+0,13 X_{1} X_{3}- \\
0.00001 X_{2}^{2}-0.17 X_{2} X_{3}+39,01 X_{3}^{2}\end{array}$ & 0,85 \\
\hline $\begin{array}{l}\text { Polifenol } \\
\text { (mg GAE / } \\
\text { 100g) }\end{array}$ & $\begin{array}{c}=4,68+0,3 X_{1}+0,22 X_{2}+18,96 X_{3}- \\
0.004 X_{1}^{2}-0.003 X_{1} X_{2}+1,2 X_{1} X_{3}- \\
0.003 X_{2}^{2}-1,49 X_{2} X_{3}+280,13 X_{3}^{2}\end{array}$ & 0,90 \\
\hline $\begin{array}{l}\text { Protein } \\
(\mathrm{mg} / \mathrm{L})\end{array}$ & $\begin{array}{c}=4499,3-130,5 X_{1}+39,3 X_{2-} \\
52090,8 X_{3}+0.53 X_{1}^{2}-0.08 X_{1} X_{2}+ \\
2190,5 X_{1} X_{3}-0.2 X_{2}^{2}-498,2 X_{2} X_{3}- \\
27685 X_{3}^{2}\end{array}$ & 0,92 \\
\hline
\end{tabular}

${ }^{*} \mathrm{X}_{1}=$ temperatur, $\mathrm{X}_{2}=$ Waktu, $\mathrm{X}_{3}=$ Konsentrasi

Sumber: Sagu et al. (2014) 
Raharja, et al., 2018

Tabel 4. Hubungan Konsentrasi Substrat Lama Waktu, \& Temperatur terhadap Aktivitas Poligalakturonase

\begin{tabular}{cccc}
\hline $\begin{array}{c}\text { Konsentrasi } \\
\text { Substrat (\%) }\end{array}$ & $\begin{array}{c}\text { Waktu } \\
\text { (jam) }\end{array}$ & Suhu $\left({ }^{\circ} \mathbf{C}\right)$ & $\begin{array}{c}\text { Aktivitas } \\
\text { PG (u/mil) }\end{array}$ \\
\hline 5 & 65,00 & 32,50 & 2,9 \\
\hline 6,01 & 56,08 & 28,04 & 1,7 \\
\hline 6,01 & 73,92 & 28,04 & 1,5 \\
\hline 6,01 & 56,08 & 36,96 & 1,9 \\
\hline 6,01 & 73,92 & 36,96 & 1,5 \\
\hline 7,50 & 65,00 & 25,00 & 2,7 \\
\hline 7,50 & 50,00 & 32,50 & 1,2 \\
\hline 7,50 & 65,00 & 32,50 & 6,2 \\
\hline 7,50 & 65,00 & 32,50 & 6,9 \\
\hline 7,50 & 65,00 & 32,50 & 5,3 \\
\hline 7,50 & 65,00 & 32,50 & 7,3 \\
\hline 7,50 & 65,00 & 32,50 & 6,7 \\
\hline 7,50 & 65,00 & 32,50 & 6,1 \\
\hline 7,50 & 80,00 & 32,50 & 3,8 \\
\hline 7,50 & 65,00 & 40,00 & 1,7 \\
\hline 8,99 & 56,08 & 28,04 & 2,7 \\
\hline 8,99 & 73,92 & 28,04 & 1,3 \\
\hline 8,99 & 56,08 & 36,96 & 1,2 \\
\hline 8,99 & 73,92 & 36,96 & 2,7 \\
\hline 10,00 & 65,00 & 32,50 & 6,9 \\
\hline
\end{tabular}

*PG: Poligalakturonase

Barman et al. (2014)

Tabel 5. Aplikasi Enzim dalam Pembuatan Sari Buah Pisang

\begin{tabular}{cccc}
\hline $\begin{array}{c}\text { Tipe } \\
\text { Enzim }\end{array}$ & Konsentrasi (\%) & $\begin{array}{c}\text { Waktu } \\
\text { (menit) }\end{array}$ & Absorbansi \\
\hline$A$ & 1 & 30 & $0,65 \pm 0,03^{\mathrm{a}}$ \\
\hline $\mathrm{B}$ & 1 & 30 & $0,37 \pm 0,02^{\mathrm{e}}$ \\
\hline $\mathrm{A}$ & 2 & 30 & $0,52 \pm 0,03^{\mathrm{c}}$ \\
\hline $\mathrm{B}$ & 2 & 30 & $0,12 \pm 0,02^{\mathrm{f}}$ \\
\hline $\mathrm{A}$ & 1 & 60 & $0,60 \pm 0,04^{\mathrm{b}}$ \\
\hline $\mathrm{B}$ & 1 & 60 & $0,33 \pm 0,03^{\mathrm{e}}$ \\
\hline $\mathrm{A}$ & 2 & 60 & $0,45 \pm 0,03^{\mathrm{d}}$ \\
\hline $\mathrm{B}$ & 2 & 60 & $0,10 \pm 0,02^{\mathrm{f}}$ \\
\hline
\end{tabular}

${ }^{*} \mathrm{~A}$ : enzim kasar, B: enzim murni sebagian

Barman et al. (2014) 
Raharja, et al., 2018

Tabel 6. Pengaruh Konsentrasi Enzim a-Amilase terhadap Kadar Gula

\begin{tabular}{cccc}
\hline $\begin{array}{c}\text { Konsentrasi } \alpha- \\
\text { Amilase }(\% \text { w/w) }\end{array}$ & $\begin{array}{c}\text { Waktu } \\
(\text { jam) }\end{array}$ & $\begin{array}{c}\text { Total Gula } \\
\text { Terlarut } \\
(\mathbf{m g} / \mathbf{m L})\end{array}$ & $\begin{array}{c}\text { Gula Pereduksi } \\
(\mathbf{m g} / \mathbf{m L})\end{array}$ \\
\hline Kontrol $^{\star}$ & & $104,25 \pm 0,67^{\mathrm{c}}$ & $64,19 \pm 2,64^{\mathrm{c}}$ \\
\hline 0 & 0 & $117,61 \pm 1,44^{\mathrm{b}}$ & $81,53 \pm 2,06^{\mathrm{b}}$ \\
\hline 0,05 & 3 & $119,50 \pm 3,31^{\mathrm{b}}$ & $89,19 \pm 3,57^{\mathrm{b}}$ \\
\hline 0,1 & 3 & $123,27 \pm 1,09^{\mathrm{b}}$ & $88,74 \pm 2,81^{\mathrm{a}}$ \\
\hline 0,3 & 3 & $127,36 \pm 3,40^{\mathrm{ab}}$ & $89,19 \pm 2,71^{\mathrm{a}}$ \\
\hline 0,5 & 3 & $127,99 \pm 1,96^{\mathrm{a}}$ & $90,99 \pm 1,56^{\mathrm{a}}$ \\
\hline
\end{tabular}

*pisang yang tidak diberikan perlakuan enzim

Cherslip dan Usmakul (2008)

Tabel 7. Pengaruh Waktu Proses Enzim a-Amilase terhadap Kadar Gula

\begin{tabular}{cccc}
\hline $\begin{array}{c}\text { Konsentrasi } \alpha- \\
\text { Amilase (\% w/w) }\end{array}$ & $\begin{array}{c}\text { Waktu } \\
\text { (jam) }\end{array}$ & $\begin{array}{c}\text { Total Gula } \\
\text { Terlarut } \\
(\mathbf{m g} / \mathbf{m L})\end{array}$ & $\begin{array}{c}\text { Gula Pereduksi } \\
(\mathbf{m g} / \mathbf{m L})\end{array}$ \\
\hline 0,05 & 3 & $119,50 \pm 3,32^{\mathrm{a}}$ & $89,19 \pm 3,57^{\mathrm{a}}$ \\
\hline 0,05 & 6 & $118,87 \pm 0,95^{\mathrm{a}}$ & $86,49 \pm 5,46^{\mathrm{b}}$ \\
\hline 0,05 & 9 & $119,50 \pm 1,44^{\mathrm{a}}$ & $87,84 \pm 2,82^{\mathrm{c}}$ \\
\hline 0,05 & 12 & $117,61 \pm 1,44^{\mathrm{a}}$ & $86,49 \pm 5,89^{\mathrm{d}}$ \\
\hline
\end{tabular}

*pisang yang tidak diberikan perlakuan enzim

Sumber: Cherslip dan Usmakul (2008)

Tabel 8. Perbandingan Wine dengan perlakuan enzim dan kontrol

\begin{tabular}{cccc}
\hline Perlakuan & $\begin{array}{c}\text { Total } \\
\text { padatan } \\
\text { terlarut } \\
\text { (Brix) }\end{array}$ & $\begin{array}{c}\text { Total Gula } \\
\text { Terlarut } \\
(\mathbf{m g} / \mathrm{mL})\end{array}$ & $\begin{array}{c}\text { Alkohol } \\
(\mathbf{m g} / \mathrm{mL})\end{array}$ \\
\hline A & $5,70 \pm 0,12$ & $2,76 \pm 0,30$ & $13,9 \pm 3,57$ \\
\hline B & $6,30 \pm 0.46$ & $5,31 \pm 1,66$ & $14,4 \pm 5,46$
\end{tabular}

A: control, B: wine dengan perlakuan enzimatis

Sumber: Cherslip dan Usmakul (2008) 
Tabel 9. Pengaruh Sonikasi Terhadap Kinerja Enzim Pektinase dan Selulase (Yield\& Viskositas)

\begin{tabular}{ccccc}
\hline $\mathbf{S ~ ( \% ) ~}$ & $\mathbf{P}$ (\%) & $\begin{array}{c}\text { Ultrasound Time } \\
\text { (menit) }\end{array}$ & Yield (\%) & $\begin{array}{c}\text { Viskositas } \\
\text { (mPa.s) }\end{array}$ \\
\hline 0 & 0 & 0 & $\begin{array}{c}47,30 \\
\pm 0,85^{\mathrm{f}}\end{array}$ & $219,00 \pm 5,29^{\mathrm{a}}$ \\
\hline 0,2 & 0 & 0 & $\begin{array}{c}64,10 \\
\pm 0,07^{\mathrm{e}}\end{array}$ & $198,67 \pm 8,50^{\mathrm{b}}$ \\
\hline 0 & 0,2 & 0 & $\begin{array}{c}71,40 \\
\pm 3,06^{\mathrm{d}}\end{array}$ & $160,33 \pm 6,80^{\mathrm{c}}$ \\
\hline 0,2 & 0,2 & 0 & $\begin{array}{c}76,2 \\
\pm 1,04^{\mathrm{c}}\end{array}$ & $158,67 \pm 3,51^{\mathrm{c}}$ \\
\hline 0 & 0 & 30 & $\begin{array}{c}49,05 \\
\pm 1,01^{\mathrm{f}}\end{array}$ & $195,33 \pm 2,08^{\mathrm{b}}$ \\
\hline 0,2 & 0 & 30 & $\begin{array}{c}77,10 \\
\pm 1,41^{\mathrm{c}}\end{array}$ & $114,33 \pm 2,89^{\mathrm{d}}$ \\
\hline 0 & 0,2 & 30 & $\begin{array}{c}85,50 \\
\pm 1,15^{\mathrm{b}}\end{array}$ & $113,67 \pm 1,53^{\mathrm{d}}$ \\
\hline 0,2 & 0,2 & 30 & $\begin{array}{c}89,40 \\
\pm 1,21^{\mathrm{a}}\end{array}$ & $118,33 \pm 1,53^{\mathrm{d}}$ \\
\hline
\end{tabular}

${ }^{*}$ S: Selulase, P: Pektinase

Sumber: (Boraet al., 2017)

Tabel 10. Pengaruh Sonikasi Terhadap Kinerja Enzim Pektinase dan Selulase (Kejernihan danTSS)

\begin{tabular}{|c|c|c|c|c|}
\hline $\mathrm{S}(\%)$ & $\mathrm{P}(\%)$ & $\begin{array}{l}\text { Ultrasound Time } \\
\text { (menit) }\end{array}$ & Kejernihan $(\% \mathrm{~T})$ & $\begin{array}{l}\text { TSS } \\
\left({ }^{\circ} \text { Brix }\right)\end{array}$ \\
\hline 0 & 0 & 0 & $51,50 \pm 2,72^{\mathrm{g}}$ & $9,00 \pm 0,46^{\circ}$ \\
\hline 0,2 & 0 & 0 & $50,60 \pm 1,67^{g}$ & $9,35 \pm 0,38^{\circ}$ \\
\hline 0 & 0,2 & 0 & $57,9 \pm 0,95^{f}$ & $\begin{array}{r}11,00 \\
\pm 0,17^{\mathrm{c}} \\
\end{array}$ \\
\hline 0,2 & 0,2 & 0 & $71,1 \pm 1,34^{\mathrm{d}}$ & $\begin{array}{r}11,65 \\
\pm 0,43^{b}\end{array}$ \\
\hline 0 & 0 & 30 & $63,70 \pm 1,21^{\mathrm{e}}$ & $\begin{array}{r}10,30 \\
\pm 0,33^{d} \\
\end{array}$ \\
\hline 0,2 & 0 & 30 & $83,90 \pm 1,73^{b}$ & $\begin{array}{r}12,20 \\
\pm 0,20^{\mathrm{a}} \\
\end{array}$ \\
\hline 0 & 0,2 & 30 & $84,90 \pm 1,18^{b}$ & $\begin{array}{r}12,40 \\
\pm 0,20^{a} \\
\end{array}$ \\
\hline 0,2 & 0,2 & 30 & $88,50 \pm 1,01^{a}$ & $\begin{array}{r}12,50 \\
\pm 0,26^{a} \\
\end{array}$ \\
\hline
\end{tabular}

${ }^{*}$ S: Selulase, P: Pektinase, TSS: Total Soluble Sugar

Sumber: Bora et al. (2017) 
Raharja, et al., 2018
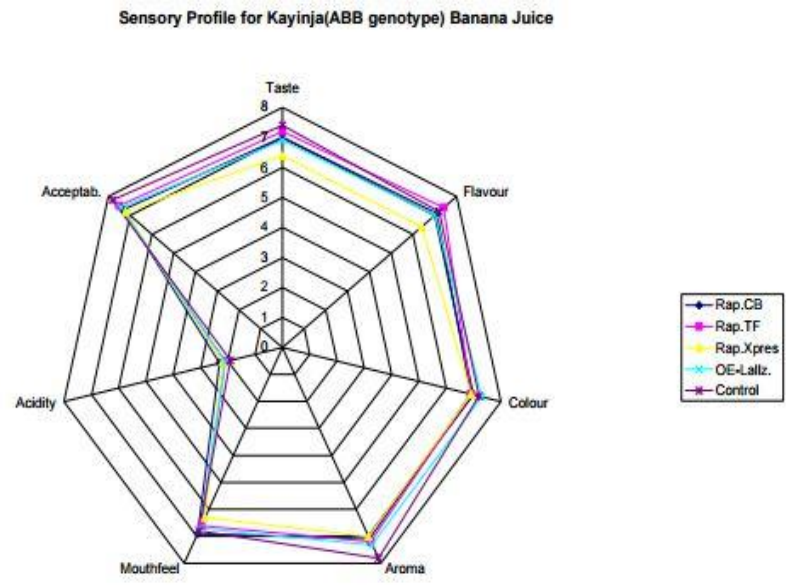

Gambar 2.Pengaruh Penggunaan Enzim terhadap Presepsi Sensoris Sari Pisang

(Byarugaba-Bazirakeet al., 2012)

Tabel 11. Pengaruh Jenis Enzim Terhadap Flavor Wine yang Dihasilkan

\begin{tabular}{cc}
\hline Wine Pisang & Deskripsi Flavor Wine \\
\hline Wine Rapidase CB & Sweet, fruity, acidic \\
\hline Wine Rapidase TF & Fruity, astringent, sweet \\
\hline Wine Rapidase Xpress & Acidic, astringent, dry \\
\hline Wine OE-Lalizzyme & Sweet, fruity, smooth \\
\hline Wine Kontrol & Sweet, light body, sour \\
\hline
\end{tabular}

Sumber: Byarugaba-Bazirakeet al. (2012) 